\title{
Local Dynamics as a Resource for Labour Protests: The Case of Wildcat Strikes in the Metal Industry in Turkey, 2012-2016
}

\author{
Isil Erdinc, Université Paris 1 Panthéon-Sorbonne, France
}

\begin{abstract}
This article analyses the role of local dynamics on trade unions' mobilisation capacity at the national level, with a focus on the wildcat strikes in the metal sector in Bursa, a city in north-west Turkey, from 2012 to 2016. It studies to what extent local dynamics such as alliances with local branches of political parties, workplace demonstrations, and local electoral and union organising campaigns contributed to protests against national government policies. The research and analysis are based on both qualitative data collected during fieldwork and on quantitative data from a variety of Turkish and international sources. Through an analysis of the wildcat strikes, the article contributes to the literature on labour movements and strikes in authoritarian contexts. Differently from the majority of the existing literature on this issue, it focuses on the workplace level rather than analysing the relations between government officials and the trade union confederations at the national level. By doing this, it shows that, despite the oppressive context at the national level, trade unions may regain power at the sectoral level.
\end{abstract}

\section{KEYWORDS}

trade unions; metal industry; Turkey; authoritarian regime; social movements

\section{Introduction}

This article analyses the role of local dynamics on the ability of a trade union movement to deal with labour conflicts at the national level. It studies the strategies of the labour unions in different industries in Turkey during the rule of the Justice and Development Party (Adalet ve Kalkinma Partisi, AKP) in a context of the rise of repressive policies vis-à-vis labour issues. It shows how local alliances make it possible for labour unions to organise strikes and gain power at the workplace level while authoritarian practices restrict labour rights and strikes at the national level.

Since its arrival to power in November 2002, the AKP has gradually transformed the relations between employers and labour unions. The AKP government uses legal regulations (Çelik, 2012), state repression, police violence and intervention in the internal affairs of trade unions in order to promote a type of "preferable and acceptable trade unionism" as opposed to a "dangerous and extremist" one (Özveri, 2012: 254-55). Nationally, unionisation strategies and new inter-union alliances (with pro-AKP unions on one side and anti-AKP unions on the other) are built around the AKP government's policies. The pro-AKP unions have gained power and have adopted more pacifist practices when there are conflicts with employers. The anti-AKP unions have been marginalised and have become unable to organise strikes and mass demonstrations. However, the study of employer-worker relations at workplace level reveals that 
the AKP government's policies do not have the same consequences there. The local (sectoral or regional) level is not equally influenced by this state intervention. There is a plurality of forces, mobilisation capacities and alliances at the local level. In the precarious sectors of activity such as the textile, shipbuilding and energy sectors - characterised by subcontracting, a high risk of dismissal and high rates of mortality at work - demonstrations and strikes are mainly organised by the marginalised trade unions. On the other hand, the pro-government trade unions are investing more in the new sectors of activity that developed throughout the 2000s such as forestry, communication, municipal and general services, banking and finance; these sectors are characterised by an increase in the employment rate, increase in incomes, and expansion in the number of companies). The local level reveals itself to be a relatively more autonomous space for the labour movement. A repressed actor of the trade union field at the national level can be the dominant actor at the local level, allowing it to obtain a larger volume of resources and more influence during collective bargaining processes. How do these marginal and sometimes even criminalised trade unions obtain rights and reinforce themselves at the workplace level? To what extent do the local configurations play a role in labour mobilisations and wildcat strikes in a context of repression of social movements?

The period of our research - between 2012 and 2016 - is interesting for three reasons. First, the AKP government's policies concerning industrial relations included a high level of control on trade unions and labour conflicts (Çelik, 2012; Özveri, 2012). Second, the power balance inside the trade union field (Béroud, 2015) was transformed during this period. Third, the trade union field became more and more polarised, and the pro-AKP trade unions gained power over the anti-AKP unions (Erdinç, 2018). This article argues that local alliances made it possible for workers and trade unions to organise strikes at the workplace level and to gain power while the authoritarian practices restricted labour rights and strikes at the national level.

The case of the metal industry in Bursa is not the only example of labour mobilisation changing the power balance in labour movements under repression. Morocco has, since 2011, witnessed the development of new forms of organising and mobilising employees around labour-related demands outside unions and legal frameworks (Zeroual and Lefnatsa, 2019). Through a focus on the actions of teachers in the public education sector, who were hired on a contractual basis, the Moroccan case also shows how these non-union dynamics confront the neo-liberal policies and austerity measures in the country. As to the labour movements in Algeria, it is the autonomous trade unions that participated in the space of contestation during the 1990s and 2000s (Beddoubia, 2019). The autonomous trade unions have managed to go beyond corporatist demands to reinforce a movement that focuses on questions of democratic change in the context of the Arab Spring. The wildcat strikes in Turkey enabled workers who were members of a pro-employer and pro-government trade union to mobilise and protest against the aggravation of conditions or unrightful dismissals.

This research is based on fieldwork conducted in Turkey between 2012 and 2016. This comprised 111 semi-structured interviews at the three main trade union confederations and their affiliates in different industries, observations in trade unions, and the analysis of the local, national and international press, trade union publications and legal regulations, court reports and witnesses' declarations. For the quantitative data, mainly the official statistics of the Ministry, European Union (EU) Development Reports, and reports of labour unions' research institutes were used. The choice of the strikes in the metal industry as a case study in this article stems from their being among the most influential strikes in Turkey during the 2000s because of their scale, results and extent of media coverage.

This article has three main objectives. First, it aims to analyse the relations between trade 
unions and the political power (political parties, government actors, deputies) (see also in this regard: Levitsky, 2003; Yousfi, 2015). Second, it seeks to understand how the social protest actors (more precisely the trade unions) construct alliances at the local level. Third, it contributes to the scholarship on social movements in repressive contexts. The existing literature on this subject focuses on the national level and on the impact of government policies on trade union strategies, ignoring the sectoral and regional contexts (Gobe, 2008; Çelik, 2015). This article shows that when we switch our focus, we discover that government policies do not have the same consequences on all sectors and regions. A different power balance between hegemonic actors and trade unions can be found. Discriminated-against and criminalised trade unions can gain power through workplace demonstrations, wildcat strikes and local political alliances. This article will first explain briefly the conceptual framework of our study. The second part will analyse two main instruments used by the AKP government in order to control and govern the trade unions and industrial relations. The third part will focus on the strikes in the metal industry in Bursa. The last part will study the consequences on the labour movement and on trade union practices. The conclusion will provide further discussion on industrial relations in an authoritarian context (Allal, Scala and Longuenesse, 2019).

\section{Conceptual Framework}

According to the legal definition, a wildcat strike is a work stoppage that occurs during the term of a collective bargaining agreement without approval of union leadership and in violation of a no-strike clause (USLegal, undated). Such strikes generally occur because labour has specific problems or concerns that have not been satisfactorily addressed by employers, or workers feel that union leaders are not acting in the best interests of the union members. In the United States legal system, it is also referred to as an "outlaw strike" (USLegal, undated). Alvin Gouldner (1954) describes a wildcat strike as a strike developed out of a violation of previously agreed conditions between the workers and the employers which comprised part of the workers' expectations. The formal issues of the dispute usually appear to be the displacement of a conciliatory official union leadership by a more aggressive informal leadership that is more representative of the workers' state of emotional tension (Gouldner, 1954).

This article aims to contribute to the existing literature on labour studies in two ways: the discussion around the concept of wildcat strike and the focus on the micro-level, in particular on the workplace level. Differently from the dominant literature on labour mobilisations under authoritarianism (Gobe, 2008; Hibou, 2011; Çelik, 2012), this article follows the invitation of Allal, Scala and Longuenesse (2019) who propose a rather micro-level analysis through a study of workplace relations, precarity and working conditions in different industries (Erdinç, 2018; Beddoubia, 2019; Spyridakis, 2019; Zeroual and Lefnatsa, 2019). We will show that authoritarian practices have different consequences at sectoral and regional levels. An oppressed trade union can play a powerful role in some industries depending on other factors such as local alliances, workers' conditions and participation, and local politics.

The research on wildcat strikes in the automobile industry in the United States and in Great Britain during World War 2 lets us understand different ways to prevent and obstruct these kinds of strikes by the political power or the contested trade union leaders (Scott and Homans, 1947; Eldridge and Cameron, 1964; Handsaker and Handsaker, 1973). Wildcat strikes in Britain, for example, were considered as an "anarchical type of protest"; they were condemned morally, and the striking workers were accused of not being loyal to existing collective agreements and of not 
respecting the industrial order and peace (Eldridge and Cameron, 1964: 33-36).

The research on wildcat strikes in authoritarian contexts shows how workers use this kind of collective action when the conventional forms of participation or union representation are no longer possible (Zetka, 1992; Anner and Xiangmin, 2016). In their work on wildcat strikes in Vietnam, Anner and Xiangmin (2016) show that workers use wildcat strikes in order to place pressure on official trade union representatives and leaders (which the authors call harmonious unions) in order to make them act on behalf of their affiliates. According to their study, the wildcat strikes in Vietnam not only provided benefits to workers but also affected state policy and engendered state transformations that shaped employment relations institutions more broadly, whether through minimum wage adjustments or labour law reforms that provided greater voice for workers at the firm level (Anner and Xiangmin, 2016: 21-23). Zetka's (1992) work on wildcat strikes in the United States between 1946 and 1963 explains the importance of the dynamics of the automobile industry in the success of wildcat strikes. He states one factor that could explain this success may be the high levels of centralisation and interdependence among production processes in the auto industry. This grants workers great power to jeopardise capital. However, in less interdependent processes (where the workers cannot coordinate their activities to accomplish their tasks), wildcat strikes may not be viable and the workers may not be able to take collective control of their work and the work procedures through strikes (Zetka, 1992: 216-24). Thus, the sectorial dynamics are decisive in order to analyse the collective action possibilities and the conditions that facilitate a wildcat strike. Moreover, in an oppressive working environment, the unofficial becomes a gesture of defiance and a protest against the fact that someone has broken the existing rules (Zetka, 1992: 36).

In addition to the discussion on wildcat strikes, this article aims to point out the importance of local workplace dynamics in understanding the possibilities of wildcat strikes in an oppressive context. The article thus pays particular attention to the local working conditions, the structure and nature of the job, working hours, employer-employee proximity, trade union membership density in the sector, political participation of the workers, and government oppression and control in the industry. In this sense, the article articulates the research on sociology of work and employment (Bevort and Jobert, 2011) and sociology of labour movements (Nowak, Dutta and Birke, 2018). Based on a study of the Confédération Générale du Travail (CGT) in France, Karel Yon (2011) states that the fact that the trade unions are organised in a decentralised way guarantees the creation and coexistence of different union actions and styles, including those that are more critical or intellectual. Thus, switching the levels of analysis in order to see different configurations on the micro level lets us find different styles of labour mobilisation (Revel, 1996). Moreover, recent research on authoritarian regimes shows how new forms of collective action are gaining ground under authoritarian regimes (Bayat, 2006; Scott, 2008; Uysal, 2017). Graeme Robertson (2007) studied strikes and labour organisations in hybrid regimes, in particular in postwar Russia, after the Cold War period. He shows that despite the introduction of electoral competition, autonomous democratic organisations representing labour are not well developed. However, this situation doesn't make workers' protests disappear completely. On the contrary:

The greater the hardship, or the perception of injustice, the more likely there is to be wildcat action, that is protest activity beyond the framework of the official unions. Where deprivation is worse, official efforts to prevent protest are less likely to be successful (Robertson, 2007: 787).

However, Robertson states that in order to understand the wildcat strikes in hybrid regimes, he lacks relevant data concerning the workplace level and the variations or regularities between the 
national and the workplace levels (Robertson, 2007: 783).

Thus in this article, the case of the wildcat strikes in the metal industry in Turkey under the AKP government will be studied from two dimensions: the political power and the employers' strategies in order to prevent or delegitimise wildcat strikes (second part of the article) and the role of local, sectoral and workplace dynamics in wildcat strikes (third and fourth parts of the article).

\section{Labour Rights under AKP Rule}

According to the annual report of the International Trade Union Confederation (ITUC), freedom of association and collective agreements declined between 2010 to 2013 (ITUC, 2013). In this article, we will focus on two main instruments used by the AKP government: creation of a "good unionism" as opposed to a "marginal" one through discourse, and intervention in internal affairs of the trade unions. We will start by giving a brief summary of the trade union confederations analysed in the article and the legal regulations in force between 2012 and 2016.

\section{Brief information on the trade union confederations analysed in the article and the legal regulations in force between 2012 and 2016}

The trade union field in Turkey is composed of three main trade union confederations coming from three different political families. The Confederation of Trade Unions of Turkey (Türkiye İşçi Sendikaları Konfederasyonu, Türk-İş), founded in 1952, is from a nationalist/centrist tendency. The Confederation of Progressive Trade Unions (Devrimci İsçi Sendikaları Konfederasyonu, DİSK), founded in 1967, comes from a socialist/social-democratic tradition. The Confederation of Real Trade Unions (Hak İşçi Sendikaları Konfederasyonu, Hak-İş), founded in 1976, is from a conservative/Islamic family. Türk-İs has the largest number of members followed by Hak-İş and DİSK. In order to conclude a collective agreement in a company, a union must recruit 50 per cent plus one of the workers at workplace level and 3 per cent of the workers in the entire sector on the national level (Law 6356, 2012). A worker must be a union member or must pay a fee to the union in order to benefit from a collective agreement signed between the union and the employer. The overall trade union density in Turkey is around 11 per cent according to official statistics declared by the Ministry of Labour Affairs and Social Security in July 2016 (Çalışma ve Sosyal Güvenlik Bakanlığ1 [Ministry of Labour and Social Security], 2016).

Having explained the structure of the trade union field, we will now move on to explain labour rights under AKP rule, with a focus on government policies in order to control and transform the trade unions and the labour movements.

\section{"Good unionism" versus "marginal unionism"}

The construction of hegemony (in the Gramscian sense) goes through a discourse on national security, but also on growth and development (Gambetti, 2009). "Good unionism" is based on several criteria regularly used in the speeches of former Prime Minister Recep Tayyip Erdoğan (now President of the Republic) and government representatives. Avoiding the organisation of demonstrations and strikes, loving one's homeland, ensuring the development of the country, and building good relations with employers and the state are the three main characteristics of an "acceptable trade union" according to the AKP government (Özveri, 2012).

First, "a good trade unionist" does not protest in the streets. Street demonstrations and 
collective action such as strikes are part of the "illegal activities of marginal unions" (Özveri, 2012). The continuity of public services and national development motivates this rejection, as illustrated in speeches by Recep Tayyip Erdoğan. On 14 March 2008, at the Gazi University in Ankara, Tayyip Erdoğan declared:

They invented a new thing now, a slowdown. It's completely illegal. It's forbidden; you cannot do that. No article allows you to do that. Imagine, they are slowing down their work in a hospital where five people are waiting. For two hours, these five people will have to wait. Now, do you know under which conditions they had arrived? Think also about bus stations and road transport. Cars will have to wait. Who will pay for the gasoline of the car that my citizen will have spent? Can you accept such a practice in the framework of a democratic, secular and social state of law when you know that we have all these problems in our cities? (Erdoğan, 2008, n.p.).

Moreover, during a speech on 30 May 2012, Erdoğan spoke about the strike of workers of Turkish Airlines (Türk Hava Yolları, THY), launched on 15 May 2012:

This strike is illegal. But it would be the same thing if it was a legal strike. Imagine what will happen if the strike lasts a long time. Who will pay the cost? Who will be in trouble? The nation, the nation will pay. THY is a strategic institution. All kinds of problems concerning this strategic institution are likely to harm the nation and give rise to a very serious decline in our country. I do not think we should let them prepare for the conditions of this decline (Erdoğan, 2012: n.p.).

The second point concerns building good relations with employers and state actors. Recep Tayyip Erdoğan's speech on 26 September 2013 in Ankara explains the type of unionism the government wants:

We have our own history, our own tradition, our own culture of professional relations. We are against the distinction between employee and employer; we want to put an end to this distinction between employer and worker. We are struggling to set up a road companionship system. Because, no life is possible neither without the employer nor without the employee. Road companions are not two rival sides. They are partners who walk the same path, have the same destiny, share the difficulties and benefits. ... These two must not behave like two enemies who can never get along and agree; this is not useful for professional relations professionals, neither for the country nor for the nation (Erdoğan, 2013: n.p.).

This discourse aims to reduce the conflicts between different interests. The importance of an inter-class reconciliation for national development is thus underlined through these speeches (Çelik, 2015).

\section{Government intervention in the internal affairs of unions}

Another tool of the AKP government is direct or indirect intervention into trade union affairs. Two examples are useful in order to understand the direct and indirect mechanisms of the government's intervention in the internal affairs of trade unions: the case of the aviation industry union (Hava-İş) and the chemical and petroleum industry union (Petrol-İş).

On 29 May 2012, a law banning strikes in the aviation sector was passed in the National Assembly (T24, 2012). Earlier that year, a conflict had arisen during the collective bargaining process between Turkish Airlines and Hava-Isss, an affiliate of Türk-İş. Following the enactment of the new law, the employees of Turkish Airlines protested the restriction. In the following days, 
Turkish Airlines sacked 305 employees who had participated in the protest. Meanwhile, the company and the trade union failed to reach agreement at the end of the collective bargaining process. Thus, the trade union began to strike on 15 May 2013, calling for the reinstatement of dismissed workers and the preparation of a new collective agreement. During the strike, on 7 December 2013, Hava-İş was to hold its general congress in Istanbul to elect its new central committee. According to the declarations of the trade union representatives and workers, the management of Turkish Airlines threatened the workers with dismissal if they supported the present union president who had launched the strike. ${ }^{1}$ Two candidates withdrew, and another candidate made an alliance with the pro-AKP candidate for presidency of the union. Thus, the president who launched the strike lost the election and the candidate close to the AKP was elected as the new president of Hava-Iss. Clearly, AKP networks played a decisive role in the election of the new executive committee of the trade union (Evrensel, 2013). Upon the arrival of the new head of the union, on 20 December 2013, the union declared the end of the strike and signed a collective agreement with Turkish Airlines according to the terms rejected by the former central committee (Bloomberg, 2013). The workers on strike were only partially reinstated to their jobs at Turkish Airlines. During our interviews with trade union representatives, the change of the central committee of the union was considered as an "operation for the pacification of the union", "an invasion by the AKP", ${ }^{3}$ and "the beginning of a period of declining struggles".

Another example is the case of Petrol-İss, a trade union in the chemicals and petroleum industry and an affiliate of Türk-İss. A union representative explains the transformations in the executive committee of the union in the period 2013 and 2015:

\begin{abstract}
In our local branches, employers started to recruit workers close to the AKP, even sometimes party members who do not have the required qualifications for the job. These workers are then encouraged to present themselves as candidates in the union elections or to vote for candidates close to the AKP. This situation led to a change in the central committees of our union. There are therefore more and more new union leaders and members supporting the AKP. These executives recruit administrative and permanent staff close to the AKP as well, while sacking or forcing to leave socialist and social-democrat staff members in the union. I'm thinking of quitting soon, too. We are no longer fighting against employers. We are becoming less and less autonomous in our decisions and training and educational activities for workers. ${ }^{5}$
\end{abstract}

In this way, the intervention of the AKP transforms indirectly or directly the central committees of the unions. The new members have different convictions and traditions than the previous committee members, and this changes the practices, activities and strategies of the trade union. The trade unions' collective action repertories change (Tilly, 1978); they become less conflictual and more consensual.

However, these transformations on the national level have different consequences at the local level. Some sectors and industries appear to have different dynamics, and trade unions find a place to organise strikes and protests at the workplace level. The following section will show how the wildcat strikes at the local level have led the workers to protest unrightful dismissals by employers, government repression of labour movements and the pro-government and proemployer trade union to whom they are affiliated.

\footnotetext{
1 Union representative 1, interview, Istanbul, 24 December 2015.

2 Union representative 2, interview, Istanbul, 27 December 2015.

3 Union representative 3, interview, Istanbul, 12 August 2014.

${ }_{4}$ Union representative 4, interview, Istanbul, 12 August 2014.

5 Union representative 5, interview, Istanbul, 25 December 2015.
} 


\section{Local Dynamics as a Resource for Collective Action: The Case of the Metal Workers' Strikes in Bursa}

It was explained in the first part of this article how the AKP government is reconfiguring the trade union field. In this context, some trade unions operate in a way that ensures they obtain state benefits such as (municipal resources, European Union projects, indirect financial resources, and direct or indirect support by AKP government officials in recruiting workers in both public and private sectors. To achieve this, they do not consider the demands of the workers, and sign agreements that give rise to worker discontent (Erdinç, 2018). The construction of good relations with employers and the discourse on the importance of "social dialogue" have started to be the rule for trade unions (Erdinç and Visier, 2018). Hence, wildcat strikes became one of the strategies for workers to protest the terms of collective workplace agreements signed by their union.

Pierre Bourdieu (1984) underlines the importance of the implantation of a company in local social life. He states that the objective relations that exist in the workplace shape the protest capacities of workers. The local level is thus important when analysing the mobilisation strategies of labour unions. A focus on the metal industry in Bursa, northwest Turkey, will let us examine the role of local actors. This part of the article will show that the inter-organisational alliances and specific sectoral configurations in the metal industry in Bursa enable the workers to gain power over dominant actors in the trade union field. This analysis will help us understand how the workers could find a way to protest and mobilise in the context of an authoritarian regime, where some of the trade union representatives are pro-government. These pro-government representatives aim to create good relations with employers in order to avoid industrial conflicts and unrest in the country.

\section{Industrial relations and collective bargaining in the metal industry in Bursa}

The metal industry in Turkey has been marked by several wildcat strikes between 2012 and 2016. Thousands of workers in the automobile companies in Bursa have refused to accept the clauses of a new collective agreement. (See Table 1 for a list of international car companies with local operations.) These mobilisations were organised without the support or approval of the union to which the workers were affiliated, in this case Türk Metal, affiliated to the nationalist/centrist Türk-İş). How can one explain the conflicts and wildcat strikes despite the collective agreement signed by the majority trade union and, more importantly, despite the repression and the restrictions on the right to strike in Turkey?

The history of the conflicts between employers and workers in the metal industry in Bursa goes back to November 2012. The first demonstrations were organised by workers affiliated to the left-wing union Birleşik Metal-İş at the Renault plant (partner of the Turkish company, Oyak), and then extended into other automotive companies in Bursa. The declaration of Birleşik Metal-İş on 4 December 2012 lets us follow the background of the conflict:

On 12th of November, workers who are working in the 16.00-24.00 shift of the Renault factory, stopped work at 18.30 and gathered in the factory square. Workers had two main demands: first, the revision of the collective agreement draft and second, the resigning from Türk Metal and [for] Türk Metal to leave the workplace. The demonstration, which started at the assembly line, spread to other divisions. The demonstration continued until midnight. Later in the night, the factory manager came to the factory and [said] that he wants to talk with a delegation of five workers, but he also threatened workers by saying that they should start production in the meantime, otherwise 
he won't be responsible [for] what will happen. Workers didn't go back to production, and they waited for the workers of the $24.00-08.00$ shift. But factory management was afraid that the demonstration will spread to next shift, too, and they cancelled the 24.00-08.00 shift. And they tried to prevent workers to meet each other. But workers didn't leave the plant and some of the workers from other shifts and workers from different workplaces in the industrial zone came in front of the factory to support the striking workers. Around 24.00, the police intervened and told the workers that according to law it is forbidden to demonstrate after 24.00 and wanted to prevent the workers waiting outside to meet the workers who will leave the factory. Some of the workers argued with the police and they [said] that they don't want to leave the factory. When the next shift came to work, 23 workers learned that they were dismissed. Also 10 other workers from the morning shift who came in front of the factory in order to show their support during the demonstration, were dismissed, too (Birleşik Metal-İş, 2012).

Table 1. Production plants of multinational automobile companies in Bursa and Kocaeli

\begin{tabular}{|l|c|c|}
\hline Name of company & Date plant established & Capital (x 1000 TL, in 2007) \\
\hline AIOS (Isuzu) & 1966 & 25419 \\
\hline BMC & 1966 & 500000 \\
\hline Ford Otosan & 1983,2001 & 350910 \\
\hline Hattat Tarım (Valtra) & 2002 & 40000 \\
\hline Honda Türkiye & 1997 & 180000 \\
\hline Hyundai Assan & 1997 & 627235 \\
\hline Karsan (Peugeot) & 1966 & 260000 \\
\hline MAN Türkiye & 1966 & 27500 \\
\hline Mercedes Benz Türk & 1968,1985 & 24000 \\
\hline Otokar (Land Rover) & 1963 & 323300 \\
\hline Oyak Renault & 1971 & 210000 \\
\hline Temsa Global (Mitsubishi) & 1987,2008 & 500000 \\
\hline Tofaş (Fiat) & 1971 & 150165 \\
\hline Toyota & 1994 & 050 \\
\hline
\end{tabular}

Source: Birlesile Metal-İs (2015).

However, the demonstrations in 2012 were not as influential as those organised through 2014 and 2015 (Güler and Tokol, 2016). In December 2014, Türk Metal and the Turkish Metal Industry Employers' Union (Türkiye Metal Sanayicileri Sendikas1, MESS) signed a collective agreement for the period 2014-2017. Türk Metal is an affiliate of Türk-Isş, which has a nationalist tendency and is known to be close to the government and to employers. Çelik-Iss, a conservative confederation and an affiliate of Hak-İs, is also known to be close to the government; it signed the same agreement, representing a small number of the companies in which it had most of the workers. Birleşik Metal-İs, on the other hand, declared itself against this collective agreement. Two clauses caused the main discontent: the conditions for the increase in wages and the duration of the collective agreement. ${ }^{6}$ The agreement provided for a wage increase proportional

${ }^{6}$ Birleşik Metal-Isss report (internal document, collected by the author during fieldwork), 2014. 
to the inflation rate. However, in the metallurgical sector in Turkey, there is a great wage gap between experienced workers and workers recruited from 2000 onwards, which represents 70 per cent of workers working in the whole sector. Thus, Birleşik Metal-İş demanded a lower increase for workers who have higher wages and a higher increase for those who have lower wages. The collective agreement was to be valid for a period of three years. However, the duration of collective agreements signed in Turkey in the metallurgical sector was generally two years. This situation restricted the bargaining capacity of the workers and made the workers lose their regular wage increase every two years.

\section{Wildcat strikes}

In this context, on 29 January 2015, Birleşik Metal-İş called for a strike in twenty-two companies in the metal industry (DISK, 2015). Workers at other automobile companies affiliated to the FiatChrysler Automobiles group (FCA) also participated in the demonstrations. Sixteen more companies joined the call to strike on 19 February. In January 2015, the executive committee of DISK, a left-wing trade union confederation with both socialist and social-democratic affiliates, declared its support for the workers on strike. However, the strike of the metalworkers, now joined by 15000 workers from forty-eight plants, was suspended for two months by the government on 30 January 2015, on the grounds of "being a threat against national security". This was the seventh strike that was suspended by the government in thirteen years (SiyasiHaber, 2015). ${ }^{7}$ These wildcat strikes in Bursa were a way that the metalworkers could protest their conditions at the workplace level. They had consequences in the whole trade union field by influencing the power balance between pro- and anti-government and employer trade unions.

The conflict between the employers and the workers in the metal industry in Bursa reached its peak in April 2015, when Bosch company and Türk Metal union signed a collective agreement. It is important to point out the influence of this collective agreement on the beginning of the wildcat strikes. The reason why Türk Metal - considered as an acceptable (Özveri, 2012) or a harmonious (Anner and Xiangmin, 2016) union - had to sign a collective agreement with a higher wage increase was to prevent its members from quitting the union and joining its main opposition, Birleşik Metal-İş. A number of Bosch workers had done so during November and December 2014. The two unions were waiting for the Labour Court's decision to see which union now held the majority and thus was eligible to sign agreements in the factory. In this context, the new collective agreement signed by Türk Metal offered a higher wage increase.

When the news of the collective agreement signed between Bosch and Türk Metal spread to other factories in the industrial zone, Renault workers affiliated to Türk Metal claimed the same rights and conditions as those proposed in this collective agreement. However, they were informed that they had to wait for the new collective bargaining period in 2017. This triggered a series of demonstrations in April 2015, organised at the Renault plant and supported by workers in other metal factories. The demonstrations and the strikes of the workers were considered as "illegal" by the Union of Turkish Metal Industry Employers (Güler and Tokol, 2016). The workers on strike were sacked by the Renault company. In order to protest this decision, other workers joined the protests. A massive wildcat strike organised by Renault workers in Bursa in May 2015 started without any prior approval of their union, Türk Metal. Thousands of workers in other multinational and local metal factories and automobile companies in Bursa started to join the demonstrations and the strikes (Güler and Tokol, 2016). From 14 May 2015 to 1 June 2015,

\footnotetext{
${ }^{7}$ For more information on the suspension of strikes in Turkey, see Çelik (2008), Caniklioğlu (2013) and Koçak (2014).
} 
the wildcat strikes continued at Renault, Ford, Türk Traktör, Tofaş, Fiat and many other local companies in the metal industry in Bursa, and spread to other cities around Bursa. Thus, the wildcat strikes appeared to be an alternative way to protest the collective agreement signed by the pro-employer trade union at the local level.

After having explained the background of the labour conflicts in Bursa, we can now analyse the consequences of these strikes on the power relations in the metal industry.

\section{Reconfiguring the power balance between trade unions: what consequences for the regulation of labour conflicts?}

The wildcat strikes and workers' demonstrations have led to changes in the balance of power within the trade union field. The non-functioning of the social dialogue system and its instrumentalisation by the AKP government have led to the weakening of the legitimacy of the dominant actors in the metal industry in Bursa - that is, pro-government trade unions and employers' associations.

The president of Türk Metal was booed by the union's affiliate workers during his visit to Bursa at the time of the mobilisations. The union has started to lose its members as the workers on strike left Türk Metal. Some of them joined the Birleşik Metal-İş and others declared that they no longer wished to join a trade union, claiming that "trade unions do not listen to the demands of the workers and they only care about their own interest and benefits from the state and employer". ${ }^{8}$ According to official statistics, from January to July 2015 the number of Türk Metal union members has declined from 177125 to 166 250. Birleşik Metal-İş has gained 5471 members, bringing its membership to 31066 workers (Güler and Tokol, 2016). Türk Metal lost its majority at the Renault plant in Bursa, as Birleşik Metal-Isş obtained the majority in some of the companies thanks to its support of the striking workers.

One of the consequences of the strikes on employers and car companies was the questioning of the legitimacy and relevance of the Turkish Metal Industry Employers' Union. One of our interviewees has informed us that from the first day of the strike some companies decided to leave the MESS and signed separate collective agreements by negotiating directly with Birleşik Metal-İs, which was supporting the workers on strike. 'The workers then declared the end of the strike and went back to production.

Another consequence of the wildcat strike was the improvement in the workers' working and living conditions. Table 2 shows the difference between the wage rise according to the agreement signed by Türk Metal and the wage rise according to the collective agreement signed after the strikes. It is clear that there has been a positive evolution in the workers' conditions at the company level after the strikes. The companies who signed a new agreement with the striking workers (independently from MESS or Türk Metal) accepted a wage rise for the workers. Thus, it is possible to state that the local relations and the wildcat strikes have assured a certain type of autonomy for the workers, trade union representatives and employers at the workplace level. Even though Birleşik Metal-İş is not capable of concluding collective agreements in workers' favour at the national level and is subject to anti-union discrimination, at the local level in Bursa the wildcat strikes have enabled the trade union to negotiate in more favourable conditions with the employer and eventually obtain a higher wage rise for the workers. This lets us state that the balance of power in the trade union field is different at the national level and at the sectoral level. Even though Türk Metal is the dominant trade union, holding the majority of union members in

\footnotetext{
8 Union representative 6, interview, Istanbul, 25 December 2015.

${ }_{9}^{9}$ Union representative 7, interview, Istanbul, 21 September 2015.
} 
the metal sector in Turkey, Birleşik Metal-İş managed to recruit members and become the dominant trade union in the metal industry in the city of Bursa. Moreover, the employer organisation MESS, dominant in the employers' field, has lost part of its membership among the companies in Bursa. The reshaping of the power balance thus concerns not only trade unions but also employers' organisations. The wildcat strikes have thus triggered a modification of the power balance in industrial relations through a change at the workplace level and in the metal industry in Bursa.

Table 2. Comparison between wage increases, by company

\begin{tabular}{|l|c|c|}
\hline Name of company & $\begin{array}{c}\text { Wage increase after the strikes } \\
\text { (per month) }\end{array}$ & $\begin{array}{c}\text { Wage increase according to } \\
\text { prior collective agreement }\end{array}$ \\
\hline Delphi & $252 \mathrm{TL}$ & $125 \mathrm{TL}$ \\
\hline Mahle & $281 \mathrm{TL}$ & $140 \mathrm{TL}$ \\
\hline Schneider Elektrik & $268 \mathrm{TL}$ & $184 \mathrm{TL}$ \\
\hline ALSTOM & $260 \mathrm{TL}$ & $195 \mathrm{TL}$ \\
\hline Schneider Enerji & $247 \mathrm{TL}$ & $185 \mathrm{TL}$ \\
\hline BEKAERT & $305 \mathrm{TL}$ & $210 \mathrm{TL}$ \\
\hline ABB & $253 \mathrm{TL}$ & $185 \mathrm{TL}$ \\
\hline DOSTEL & $204 \mathrm{TL}$ & $148 \mathrm{TL}$ \\
\hline
\end{tabular}

Source: Birlessik. Metal-Iss report on metal industry in Bursa gathered during fieldwork.

\section{Conclusion}

To sum up, this article has analysed two main dimensions of wildcat strikes. The first dimension concerns the grounds on which employers, the political power and official unions condemn the wildcat strikes, both morally and legally. Differently from the workers on strike during World War 2 in the US and British automobile industry (Scott and Homans, 1947; Zetka, 1992), the workers on strike in Turkey under AKP rule in the 2000s were not the elite or the more advantaged group of workers. The metal workers participating in the wildcat strikes protested the clauses and the conditions of the collective agreement signed between the employer and the official trade union. At first, their aim was to push the existing representative trade union to provide better working conditions and wages. However, in the context of an oppressive employer and government, and a non-responsive official trade union, the workers aimed to change completely the existing industrial order by changing their union affiliation. The wildcat strikes of metalworkers in Bursa revealed two problems concerning the labour conflicts in the metal industry in Turkey. In the absence of collective bargaining mechanisms that operate in accordance with international conventions and constraints of European legal regulations, state actors, employers and trade unions close to the government weighed more heavily in collective bargaining processes. The pro-government and pro-employer trade unions holding the majority at the workplace begin to lose legitimacy among their members, and therefore their ability to negotiate with employers. Thus, when we come back to our main argument, we can state that the wildcat strikes that gained force enabled the minority labour unions to obtain a space for resistance. 
The second contribution of our article concerns the impacts and the frequency of the wildcat strikes on national, local and workplace levels. Following Robertson's (2007) proposition in his research on strikes and labour organisations in hybrid regimes, we have analysed the metal industry through a micro-level analysis based on several companies in Bursa, a city in northwestern Turkey. First, the case of Turkey lets us analyse labour movements and strikes in authoritarian contexts that we can define as hybrid regimes (Levitsky, 2003), competitive authoritarianisms (Levitsky and Way, 2011) or illiberal democracies (Zakaria, 1997). The case of the metal industry lets us state three main points. In this sense, the article first shows that government repression of the labour movement does not have the same consequences in all industries, all regions and all trade unions. Spaces for labour protests and strikes are still seen in precarious sectors and in major industrial zones. The marginalised trade unions can gain influence at the workplace level during the collective bargaining process in multinational and local companies. Second, the article lets us understand how the local dynamics reinforced the marginalised and banned activities of the trade unions and workers in an authoritarian context. Thus, the local level (with its resources and actors) is used as a stake to put pressure on the employers and to overcome government repression. Third, this article has let us explain what happens to the official trade union and to the employer during and after the wildcat strike period. In a context when the behaviour of organisations nominally representing labour is of particular interest because hierarchical unions are a frequent inheritance from authoritarian regimes (Robertson, 2007: 781), the analysis of how the marginalised and criminalised trade unions and their affiliates survive through local political alliances and wildcat strikes enlightens the problems of labour representation in oppressive industrial orders.

In conclusion, we can state that in order to understand why wildcat strikes are rare and in which conditions they have an opportunity to occur and to succeed in their demands, a multilevel analysis is crucial. Thus, this article invites us to study other industries and sectors. A comparison between highly unionised sectors such as mining, energy or municipal services and less unionised sectors such as construction or textile could provide insight into the conditions and the consequences of wildcat strikes.

\section{REFERENCES}

Allal, A., M. Scala and É. Longuenesse (2019) Situations de travail et mobilisations ouvrières en Méditerranée. Confluences Méditerranée, 111(4): 9-14.

Anner, M. and L. Xiangmin (2016) Harmonious Unions and Rebellious Workers: A Study of Wildcat Strikes in Vietnam. ILR Review, 69(1): 3-28.

Bayat, A. (2006) Ortadoğu'da Maduniyet. Toplumsal Hareketler ve Siyaset. Istanbul: İletişim Yayınları.

Beddoubia, S. (2019) Les syndicats autonomes en Algérie: Initiateurs des luttes démocratiques? Confluences Méditerranée, 111(4): 119-134.

Béroud, S. (2015) Sur la pertinence heuristique du concept de champ syndical. In Bourdieu et le travail, edited by M. Quijoux. Rennes, France: PUR.

Bevort, A. and A. Jobert (2011) Sociologie du travail. Les relations professionnelles. Paris: Armand Colin.

Birleşik Metal-İş (2012) Metal Workers Anger in Renault and Arçelik towards "Yellow Union" Turk Metal. 23 November 2012. https://www.youtube.com/watch?v=iMJTQjLSZs0\&fbclid =IwAR0MXncBsFpSvFMcqD6EE7q4j3eZnVaja3CURJ7DfuRVLXabpCoMcUpkTYg

(accessed 3 November 2019). 
Birleşik Metal-İş (2015) Report on the Situation in the Metal Industry in Bursa. Internal document.

Bloomberg (2013) THY grevi sona erdi. 20 December 2013. http://www.bloomberght.com/haberler/haber/1477153-thy-grevi-sona- erdi

Bourdieu, P. (1984) Questions de sociologie. Paris: Les Editions Minuit.

Caniklioğlu, N. (2013) 6356 Sayılı Kanuna Göre Grev Yasakları ve Grevin Ertelenmesi. Callşma ve Toplum, 2013(4): 289-316.

Çalışma ve Sosyal Güvenlik Bakanlı̆̆1 [Ministry of Labour and Social Security] (2016) 2016 Temmuz Ay1 İstatistikleri. https://www.ailevecalisma.gov.tr/media/1261/2016 temmuz 6356-4.pdf

Çelik, A. (2008) Milli Güvenlik Gerekçeli Grev Ertelemeleri. Çalısma ve Toplum, 18(3): 87-132.

Çelik, A. (2015) AKP döneminde sendikal haklar : Sendikasız-grevsiz kaynaşmış bir kitleyiz! In Himmet, fitrat, piyasa. AKP döneminde sosyal politika, edited by Aziz Çelik and Meryem Koray. Istanbul: İletișim Yayınlar1.

Çelik, Z. (2012) Sendikal mücadelede yeni bir sayfa: Sendikalar ve Toplu İş Sözleşme Yasası. 21 October 2012. http://www.sendika.org/2012/10/sendikal-mucadelede-yeni-bir-sayfasendikalar-ve-toplu-is-sozlesme-yasasi-zeynep-celik

Dabene, O., V. Geisser and G. Massardier (2008) Autoritarismes démocratiques. Démocraties autoritaires au XXIe siècle. Paris: La découverte.

DİSK (2015) DİSK/Birleşik Metal-İş 29 Ocak'ta greve gidiyor. 14 January 2015. http://disk.org.tr/2015/01/diskbirlesik-metal-is-29-ocakta-greve-gidiyor

Eldridge, E.T. and G.C. Cameron (1964) Unofficial Strikes: Some Objections Considered. The British Journal of Sociology, 15(1) 19-37.

Erdinc, I. (2018) Syndicats et politique en Turquie. Les resorts sociaux du pouvoir de l'AKP (2012-2015). Paris: Dalloz.

Erdinc, I. and C. Visier (2018) Droits sociaux et "dialogue social", grandeur et décadence d'une notion. In La Turquie d'Erdoğan. avec ou sans l'Europe, edited by C. Visier. Rennes, France: PUR.

Erdoğan, Recep Tayyip (2008) Erdoğan: İş yavaşlatma eylemi yasal değil. Sabah, 14 March 2008. http://arsiv.sabah.com.tr/2008/03/14/haber,B466F4146C6A496FA1B2449C502037F1.html (accessed 12 August 2015).

Erdoğan, Recep Tayyip (2012) Erdoğan: Grevin bedelini millet öder. 30 May 2012. http://t24.com.tr/haber/erdogan-grevin-bedelini-millet-oder,205179 (accessed 12 August 2015).

Erdoğan, Recep Tayyip (2013) Başbakandan işçi ve memurlara flaş öneri. 26 September 2013. https://www.trthaber.com/haber/gundem/isci-ve-memurlara-flas-oneri-102380.html (accessed 3 November 2019).

Evrensel (2013) Hava-İș Genel Kuruluna AKP ve Türk-İș müdahalesi. Evrensel, http://www.evrensel.net/haber/73648/hava-is-genel-kuruluna-akp-ve-turk-is-mudahalesi (accessed 7 December 2013).

Gambetti, Z. (2009), İktidarın dönüşen çehresi : Neoliberalizm, şiddet ve kurumsal siyasetin tasfiyesi. İ.Ü. Siyasal Bilgiler Dergisi, 40(3): 145-166. 
Gobe, É. (2008) Les syndicalismes arabes au prisme de l'autoritarisme et du corporatisme. In Autoritarismes démocratiques. Démocraties autoritaires an XXIe siècle, edited by O. Dabène. Paris: La Découverte.

Gouldner, A. (1954) Wildcat Strike. Yellow Springs, OH: The Antioch Press.

Güler, C. and A. Tokol (2016) İşçilerin Gözünden Bir Direniş Hikâyesi: 2015 Metal Direnişi. Atatürk Üniversitesi İktisadi ve İdari Bilimler Dergisi, 30(5): 935-968.

Handsaker, M. and M.L. Handsaker (1973) Remedies and Penalties for Wildcat Strikes: How Arbitrators and Federal Courts Have Ruled. Catholic University Law Review, 22(2/3): 279-323. http://scholarship.law.edu/lawreview/vol22/iss2/3 (accessed 23 September 2020).

Hibou, B. (2011) Anatomie politique de la domination. Paris: La découverte.

International Trade Union Confederation (ITUC) (2013) Turkey: More Than 100 Trade Unionists Arrested. http://www.ituc- csi.org/turkey-more-than-100-trade (accessed 2 April 2013).

Koçak, H. (2014) Şişecam grevi üzerinden değişenler, değişmeyenler ve görevler. Başlangı̧, 8 July 2014.

Levitsky, S. (2003) From Labour Politics to Machine Politics: The Transformation of PartyUnion Linkages in Argentine Peronism, 1983-1999. Latin American Research Review, 38(3): 336.

Levitsky, S. and L. Way (2011) Competitive Authoritarianism: Hybrid Regimes after the Cold War. Cambridge: Cambridge University Press.

Nowak, J., M. Dutta and P. Birke (2018) Workers' Movements and Strikes in the Twenty-first Century. A Global Perspective. London: Rowman and Littlefield International.

Özveri, M. (2012) Sendikal Haklar. 6356 Sayıh Sendikalar ve Toplu Ișs Sözleșmesi Yasası. Istanbul: Birleşik Metal-İş Yayınları.

Revel, J. (1996) Jeux d'échelles. La micro-analyse à l'expérience. Paris: Gallimard.

Robertson, G. (2007) Strikes and Labor Organization in Hybrid Regimes. American Political Science Review, 101(4): 781-798.

Scott, J. (2008) La domination et les arts de la résistance: Fragments du discours subaltern. Paris: Amsterdam.

Scott, J. and C. Homans (1947) Reflections on the Wildcat Strikes. American Sociological Review, 12(3): 278-287.

Spyridakis, M. (2019) Living in Crisis. An Ethnography of Precarious Employment in the Shipbuilding Industry of Piraeus. Confluences Méditerranée, 111: 89-103.

SiyasiHaber (2015) İşçi düşmanı karar: Grev ertelendi. 30 January 2015. http://siyasihaber4.org/isci-dusmani-karar-grev-ertelendi (accessed 9 April 2019).

T24 (2012) THY çalışanlarına grev yasağ1 getirildi. 30 May 2012. http://t24.com.tr/haber/thycalisanlarina-grev-yasagi- getirildi, 205173.

Tilly, C. (1978) From Mobilization to Revolution. Boston, MA: Addison-Wesley.

USLegal (Undated) Wildcat Strike Law and Legal Definition. https://definitions.uslegal.com/w/ wildcat-strike (accessed 14 August 2020).

Uysal, A. (2017) Sokakta Siyaset. Türkiye'de Protesto Eylemleri, Protestocular ve Polis. Istanbul: İletişim Yayınlar1. 
Yon, K. (2011) La CGT-FO aux marges du mouvement ouvrier: Recomposition et isolement d'un milieu syndical dans les années 1970. In Les Meuniers du social: Force ouvrière, acteur de la vie contractuelle et $d u$ paritarisme, edited by M. Dreyfus and M. Pigenet. Paris: Presses Universitaires de la Sorbonne.

Yousfi, H. (2015) L'UGTT, une passion tunisienne. Enquête sur les syndicalistes en révolution (2011-2014). Paris: Karthala.

Zakaria, F. (1997) The Rise of Illiberal Democracy. Foreign Affairs, 76(6): 22-43.

Zeroual, A. and A. Lefnatsa (2019) Les nouvelles formes d'organisation de la résistance salariale au Maroc. Confluences Méditerranée, 111(4): 105-118.

Zetka, J. (1992) Work Organization and Wildcat Strikes in the U.S. Automobile Industry, 1946 to 1963. American Sociological Review, 57(2): 214-226.

\section{BIOGRAPHICAL NOTE}

IsIL ERDINC holds a $\mathrm{PhD}$ in political science from Paris 1 Panthéon-Sorbonne University. She is currently teaching in Paris. Her research interests are labour movements, political economy, trade unions, political regimes and social policy. [Email: isil.erdinc@univ-paris1.fr] 